\title{
Anti-Black Racism in Education: School Leaders' Journey of Resistance and Hope
}

\author{
Ann E. Lopez
}

\section{Contents}

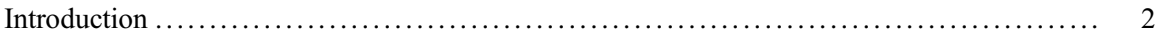

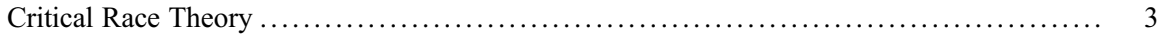

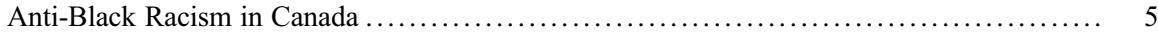

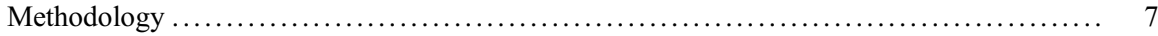

School Leaders' Experiences of Anti-Black Racism $\ldots \ldots \ldots \ldots \ldots \ldots \ldots \ldots \ldots \ldots \ldots \ldots \ldots, \quad 8$

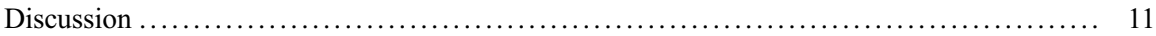

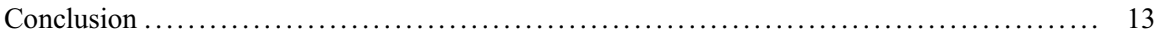

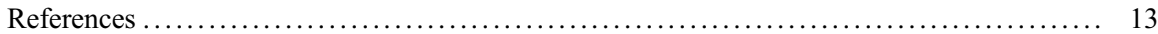

\section{Summary}

Anti-Black racism is present in Canadian society and schools, but often buried within a multiculturalism discourse. Black educators in Canadian schools experience discrimination, exclusion, and oppression grounded in anti-Black racism which is often not acknowledged in the inclusion, diversity, and equity discourse. In this chapter, drawing on Critical Race Theory, my own lived experiences as a former secondary school teacher and administrator in Ontario, Canada, and research I conducted, I examine the impact of anti-Black racism on Black school leaders in the Greater Toronto Area (GTA). Utilizing a narrative inquiry approach, I explore the impact of anti-Black racism on their leadership journey. Data continue to show that while the student population in the GTA is becoming increasingly more diverse, those in formal positions of leadership remain predominantly White. The absence of Black bodies in positions of leadership in education is not due to a lack of interest by Black people in leadership but the result of historical barriers and systemic oppression. Through these narratives,

\footnotetext{
A. E. Lopez $(\square)$

Department of Leadership, Higher and Adult Education, Ontario Institute for Studies in Education, University of Toronto, Toronto, ON, Canada

e-mail: ann.lopez@utoronto.ca
} 
I seek to highlight the harm done when anti-Black racism is not challenged and suggest policies and practices focused on the recruitment, retention, and support of Black school leaders.

\section{Keywords}

Anti-Black racism $\cdot$ Critical race theory $\cdot$ Decolonizing education $\cdot$ School leadership $\cdot$ Narrative Inquiry

\section{Introduction}

As we navigate our daily lives in different spaces and contexts, we experience the world and the world experiences us. What we experience in these spaces is based on varying aspects of our identity such as class, gender, race, sexual identity, religious beliefs, and so on. I am a Black woman, scholar, and educator born and raised in Jamaica, living in Toronto, Canada. I navigate the world as Black woman, analyze and make sense my experiences through these lenses. As I move along my own education journey, I have come to understand that if we are to create transformative change in education, it is important to create space for Black people to examine and share their experiences. While conversations on diversity and equity are important, that cannot be the only space where issues relating to Black people are discussed. Black people experience racism and oppression in ways that are unique to their history and context.

Globally anti-Black racism, xenophobia, racism, white nationalism, anti-Semitism, and other forms of discrimination and exclusion are on the rise. Examples of this troubling trend can be seen in many countries where minority populations are being victimized and immigrants treated in inhumane ways. In North America, Native Americans, First Nations Peoples, Black and Brown people have always experienced racism (In Canada the term First Nations Peoples are used to refer to the original inhabitants of the land. Sometimes the term Indigenous is also used.). However, in recent times there is a boldness that is frightening and worrisome. As Western societies become more diverse due to demographic shifts, there appears to be a ramping up of hate and bigotry, and ways that racism is manifesting itself. Regardless of the forms it takes, racism must be named and challenged. Delgado and Stefancic (2000) prominent critical race theory scholars remind us that racism is normal, and an ingrained feature of the social fabric of society looks ordinary and natural to people in the culture.

In the United States, the election of Donald Trump has brought to the forefront a social discourse that is anti-immigrant and openly racist. Trump's election has ushered in the scourge of authoritarianism, the toxic language of hate, humiliation and bigotry, and the emergence of a culture of war (Giroux, 2017). The discourse of hate and bigotry is ever so present in all aspects of society and none more so than education, from Kindergarten to higher education. Even before Trump's election, colleges have been shown to be racialized environments where minority students often feel hostility and unsafe (Feagin, Hernan, \& Imani, 1996; Lewis, Chesler, \& Forman, 2001). Bauer-Wolf (2017) noted incidents of racial hatred towards minority 
students at various universities in the USA. These incidents included racial slurs, use of the $\mathrm{N}$ word, swastika drawn on buildings and the spread of white nationalist propaganda. The US Department of Education (2016) data show an increase of hate crimes on college campuses motivated by biases of race, national origin, ethnicity, religion, sexual orientation, gender, or disability. Kohli, Pizarro, and Nevarez (2017) suggest that the rhetoric of Donald Trump has heightened public discourse on racism in $\mathrm{K}-12$ schools, and call on educators to not only challenge this phenomenon, but also pay attention to the mechanisms of racial oppression. While these conditions have pushed epistemological issues and uncertainties for educators (Fallace, 2017), there are possibilities for reflection, action, and healing as we seek to critically engage in anti-oppressive practices in order to create transformative possibilities for ourselves and others (Kumsa, Mfaofo-McCarthy, Oba, \& Gaasim, 2014). Kohli, Pizarro, and Nevarez argue further that until we concretely name racism as a problem, educators will be challenged to resolve the glaring racial disparities within the educational system.

I write this chapter with the understanding of someone whose education has been deeply impacted by colonization and colonial education, creating convergences between decolonial education and anti-Black racism. I seek to explicate these further within the context of educational leadership discourse. I have come to understand my racial identity as a site of resistance through which I seek transformative change in my quest to improve the lives of Black people in educational settings to challenge and transgress white supremacy (Newton, 2017). I begin by looking at ways that Critical Race Theory helps us to analyze race and racism in society and particularly in education and anti-Black racism in Canada. Secondly, I outline the methodological approach to my research, and thirdly, I share examples drawn from the narratives of how school leaders experience anti-Black racism. Lastly, I suggest ways that policymakers can become more purposeful and create polices that directly address the recruitment, support, and retention of Black school leaders. This includes decolonizing approach to school leadership that challenges white supremacy and the ways this is manifested in leadership practices.

Their narratives and experiences not only inform how we can engage in praxis but are an embodiment of personal agency. Understanding this embodiment is important in examining how anti- Black racism, colonialism, and white supremacy are manifested in day-to-day policies and practices (Doret \& Gordon, 2018). Antiracist resistance for racial justice can score stunning victories, but progress is never wholly secure (Gillborn, 2018) so we must continue to seek out news ways of challenging injustice, no matter the form it takes.

\section{Critical Race Theory}

As we think about the challenges we face today, it is useful to remind ourselves the conditions under which Critical Race Theory was theorized to address the challenges faced by people of color. Delgado and Stefancic (2007) noted in a speech delivered at inaugural colloquium at John Jay College: 
Critical race theory sprang up in the late 1960s and early 1970s when a number of lawyers and law professors around the country realized that the heady gains of the Civil Rights era had stalled and in many cases were being rolled back. Fresh approaches were needed to deal with the new types of colorblind, subtle, or institutional racism that were developing and a public that seemed increasingly tired of hearing about race (p. 1).

Many of these conditions still exist today and make CRT very relevant to the current discourse on race in the USA, Canada, Australia, and other economically advanced countries. There are convergences of CRT and anti-Black racism as Black people theorize their experiences. Dumas and Ross (2016) suggest:

CRT enters the field of education as a decidedly Black theorization of race. That is, even as CRT is offered as a tool to analyze race and racism in general, it is, at its inception in education (and arguably, in legal studies as well), an attempt to make sense of and respond to institutionalized racism, as this racism is experienced and endured by Black people. It is not that Ladson-Billings and Tate (1995) understood the applicability of CRT as limited to Black people; rather, it is that their explication of CRT centers most decidedly on anti-Black racism. Therefore, one might be tempted to argue that CRT is - inherently - a Black Critical Theory. But it is not a theorization of blackness or even the Black condition; it is a theory of race, or more precisely, racism, based on analysis of the curious administration of laws and policies intended to subjugate Black people in the United States. Although heavily imbued with concern for the psychic and material condition of Black subjects, individually and collectively, CRT in education functions much more as a critique of White supremacy and the limits of the hegemonic liberal multiculturalism (McLaren, 1995; Melamed, 2011), which guides policy, practice, and research in the field. Understanding this distinction between a theory of racism and a theory of blackness (in an anti-Black world) is key (p. 416).

As a theory, CRT is a race-conscious approach to examining inequities that impact people of color; supports a narrative approach; centralizes voices, experiences, and perspectives of racialized people; and uses a race-conscious approach to assess social, political, economic, and legal norms, systems, institutions, and practices (Ladson-Billings \& Tate, 1995). CRT challenges ahistoricism by stressing the need to understand racism within its social, economic, and historical context (Matsuda, Lawrence, Delgado, \& Crenshaw, 1993). There are many ways of thinking about CRT as a framework for analyzing the experiences of Black people and other racialized and oppressed groups. There is no single fixed notion and construct of CRT (Delgado, 2009; Taylor, 2016).

CRT has developed and expanded over the years and employed by many scholars in various contexts (Warmington, 2014). Nonetheless, there are key tenets that critical race theorists advocate for. These include notions that racism is ordinary, not exceptional; its ordinariness makes racism hard to recognize; race and races are products of social thought and categories that society invents for particular purposes; and posits colorblind liberalism as a cure for racial ills because it only serves to sidestep the major issues (Delagado \& Stefancic, 2007).

While CRT has evolved and expanded, one integral aspect and core tenet is that CRT recognizes race as a social construct, constantly shaped by political forces, and provides a framework through which racial subjugation can be named and eliminated. Racism is endemic and typical, not aberrational and the pervasiveness and 
ordinariness of racism makes it difficult to address (Ladson-Billings, 1998). Delgado and Stefancic (2000) expands on this notion. They posit that:

Critical race theory begins with a number of basic insights. One is that racism is normal, not abberant, in American society. Because racism is an ingrained feature of our landscape, it looks ordinary and natural to persons in the culture. Formal equal opportunity - rules and laws that insist on treating blacks and whites alike can thus remedy only the more extreme and shocking forms of injustice, the ones that do stand out. It can do little about the businessas-usual forms of racism that people of color confront everyday and that account for much misery, alienation, and despair (p. xvi).

CRT acknowledges that society is not race-neutral but structured in ways that directly and indirectly sustain white supremacy and perpetuate the exclusion of, and disadvantage and exploitation of people of African- descent and their communities (Aylward, 1999). Critical race theorists argue that the majority of racism remains hidden beneath a veneer of normality and it is only the more crude and obvious forms of racism that are seen as problematic by most people (Gillborn, 2015). CRT is not a one-dimensional approach to the issue of race but recognizes that oppressed people can experience oppression through various aspects of their identities. "For all of its emphasis on the central role of racism in shaping contemporary society, many CRT scholars are keen to explore how raced inequities are shaped by processes that also reflect, and are influenced by, other dimensions of identity and social structure" (Gillborn, 2015, p. 278). CRT utilizes critical interest convergence, social constructionism, differential racialization, storytelling, and the critique of White normativity to help us understand anti-Black racism, not only against Black people but other oppressed racial groups (Delgado \& Stefancic, 2007).

\section{Anti-Black Racism in Canada}

In teaching and learning spaces, Black educators and students are subject to oppression in the form of anti-Black racism (Newton, 2017). Mullings, Morgan, and Quelleng (2016) suggest that in Canada there is fear of the Black body. This is perpetuated through the media, treatment of Black people by the police, and stereotypes of African Canadians. Mullings et al., argue further that the image of Canada as a space where diversity is acknowledged and accepted hides ongoing anti-Black racism which they argue is pervasive in the Canadian society.

To fully examine anti-Black racism, it is important to explore how race has been positioned historically within broader social discourse. Haney-Lopez (1994) argues that:

Race must be understood as a sui generis social phenomenon in which contested systems of meaning serve as the connections between physical features, races, and personal characteristics. In other words, social meanings connect our faces to our souls. Race is neither an essence nor an illusion, but rather an ongoing, contradictory, self-reinforcing process subject to the macro forces of social and political struggle and the micro effects of daily decisions (p. 2). 
Race is socially constructed through racial categories that are produced, contested, and altered within historical contexts and political projects (Wun, 2016). Smith (2012b) argues that our identities are multiple and intersecting, and as such racial theories must include an intersectional analysis of settler colonialism and the logics of white supremacy to better understand the contestations and violence that is inflicted on some bodies.

Anti-Black racism is a form of racism that is directed against Black people and their resistance to such oppressions (Benjamin, 2011). The legacy of anti-Black racism and the ongoing denial of Black people of their basic humanity reflect the "afterlife of slavery" that continually situates Black peoples as objects of fetish and force (Sexton, 2010, 2015). According to Turner (2015) despite efforts to be more inclusive, anti-Black racism continues to permeate public education in Canada. AntiBlack racism challenges the popularly held narrative of Canada as a welcoming, safe haven for enslaved Africans escaping to freedom, and as a country where race relations with Black people lacked the viciousness of American slavery and segregation. Legalized slavery and segregation is also rooted in Canadian history (City of Toronto, The Toronto Action Plan to Confront Anti-Black Racism, 2017). Despite Canada's reputation for promoting multiculturalism and diversity, Canada's history of enslavement, racial segregation, and marginalization has had a deleterious impact on people of African descent (Office of the United Nations High Commissioner for Human Rights (OHCHR), 2016).

In 1992 in a report on race relations in Ontario Dr. Akua Benjamin identified antiBlack racism as an issue in Canada to be addressed. In the 1992 report Stephen Lewis noted:

\footnotetext{
First, what we are dealing with, at root, and fundamentally, is anti-Black racism. While it is obviously true that every visible minority community experiences the indignities and wounds of systemic discrimination throughout Southern Ontario, it is the Black community which is the focus. It is Blacks who are being shot, it is Black youth that is unemployed in excessive numbers, it is Black students who are being inappropriately streamed in schools, it is Black kids who are disproportionately dropping-out, it is housing communities with large concentrations of Black residents where the sense of vulnerability and disadvantage is most acute, it is Black employees, professional and non-professional, on whom the doors of upward equity slam shut. Just as the soothing balm of 'multiculturalism' cannot mask racism, so racism cannot mask its primary target (p. 2).
}

Doret and Gordon (2018) suggest that the fear of Blackness is implicated in its dayto-day practices and schools are no exception. This is manifested in the push-out of Black students (Dei, 2003) and continued stereotyping of Black parents. The continued fear of Black youth reveals the persistence of anti-Black racism that continues in the new millennium to plague the socio-political body (Doret \& Gordon, 2018). Antiblack racism is not limited to particular time periods or projects, anti-Black racism is systemic, pervasive, and productive (Feagin, 2013). As we examine the impact of antiBlack racism Sexton (2010) calls for the disruption of the Black/White binary and suggests that anti-Black racism is not just about white on Black racial oppression but also includes the relationship that other groups have to Black people. 
James and Turner (2017) found that Black students in the Toronto District School Board (TDSB) were suspended from school at a greater rate than other students and placed academic streams below their abilities. Ruck and Wortley (2002) examined the perceptions of differential treatment relating to school disciplinary practices among racially and ethnically diverse high school students in the Toronto metropolitan area. Ruck and Wortley found that racial and ethnic minority students are much more likely than White students to "perceive discrimination with respect to teacher treatment, school suspension, use of police by school authorities, and police treatment in school" (p. 190). Research conducted in the USA also found similar patterns with regards to the discipline of Black and Latino students (See for example Sojoyner, 2013; Wallace et al., 2008). Sexton (2007) suggests that the over disciplining of the Black people is an expression of anti-Black racism. Sexton argues further that within the context of anti-Black racism, punishment is primary and foundational to Black subjection, with discipline as a popular aspect of cruelty.

\section{Methodology}

Research that informs this chapter was conducted in the Greater Toronto Area (GTA) in the province of Ontario with Black school leaders (principals, vice principals, resource teachers). The notion of leadership that undergirds this work is that anyone can lead and leadership does not reside soley in formal administrative roles.

Participants were asked to share their experiences as racialized school leaders on their leadership journey. At the time of research, the term racialized was used in the research question. However, the responses that were analyzed were from participants who self-identified as Black. All participants at the time of the study worked in publicly funded elementary and secondary schools in the GTA. Participants were selected through convenience and snow-ball sampling (Vogt, 1999). The study included female school leaders who agreed to participate in the study. This was not intentional but based on responses to call for participants. The number of Black men in formal leadership roles in Ontario is a small number compared to their White counterparts. Kafele (2012) suggests that African American males are failing in the current education system, and this eliminates the number of African American males who graduate from school and go on to college (Noguera, 2003) and are available for leadership roles in education.

The research employed a qualitative research approach (Creswell, 2013), specifically narrative inquiry (Clandinin \& Connelly, 2000) that focuses on the experiences of participants. The narrative approach involves telling of stories that are contextually and temporally bound, that leads to rich, in-depth understandings (Bruner, 2002). Narrative Inquiry allows researchers to better understand the research context through the experiences and stories of research participants (Clandinin \& Connelly, 2000). Rich description of participants' experiences and exploration of the meanings that the participants derive from their experiences, amplifies the voices that might have remained silent (Trahar, 2013). "Narrative inquiry has an underlying philosophy and access that enables the illumination of 
real people in real settings through the 'painting' of their stories. It is a methodology in which the researcher attempts to illuminate the meanings of personal stories and events" (Wang \& Geale, 2015, p. 1).

\section{School Leaders' Experiences of Anti-Black Racism}

Gillborn (2015) suggests that the primacy of racism is manifested in a number of ways, one of which is through the issue of the personal or autobiographical experiences, represented by the dimensions of the social world and our lived reality where we try to make sense of our experiences and agency. In this section, I highlight narratives of school leaders as they navigate their leadership journey. In doing so notions of neo-liberal, common-sense learning have to be disconnected from any viable sense of political agency and notion of civic literacy and we must produce a discourse in which people recognize their problems, the conditions that produce them. This is not just a political but a pedagogical challenge in which education becomes central to any viable notion of resistance (Giroux, 2017).

From their narratives, school leaders felt anti-Black racism was a constant feature of their leadership journey, experienced mainly through racial microaggressions. Anti-Black racism in education is being acknowledged more in Canada and the education system. Prime Minister of Canada, Justin Trudeau in 2018 acknowledged the presence of anti-Black racism in Canada and urge Canadians to recognize that anti-Black racism and unconscious bias does exist. The province of Ontario in 2017 unveiled Ontario's Anti-Black Racism Strategy which sets out the elimnation of disparity outcomes for Black Ontarians in the child welfare, education, and justice sectors by 2024 as one of its goals.

An example of the anti-Black racism experiences that Black school leaders experienced was the challenging of their knowledge, and in instances made to feel that they were in leadership positions through affirmative action, and not their knowledge, skills and competence. A vice principal in a secondary school said that when she was promoted she did not get the respect she felt she deserved from the staff and was made to feel that she did not earn her position:

\footnotetext{
When I was first promoted it was perceived by some colleagues that it was more about affirmative action and that I didn't have the requisite skills to be in the role. I felt I had to prove myself. I had to be better than the average vice principal. I had to be knowledgeable, on top of my game constantly. My successes come from my determination to make a difference for students, in particular students of color and more specifically Black students. I see firsthand the struggles they encounter in the system.
}

In Ontario diversity and equity are at the forefront of conversations not only K-12 schools but in higher education. For most Black people there seems to be a dissonance between the rhetoric on diversity and equity and addressing directly the racism faced by Black people. Despite the diversity rhetoric, anti-Black racism and the vulnerability of Black communities in Ontario continues unabated 
(Benjamin, 2011). Tinsley-Jones (2003) suggests that Black people experience subtle and blatant exclusion and marginalization in employment, health care, and social settings. This leaves Black people feeling tired having to navigate these contexts.

Black people have always had to work harder than their White counterparts to prove themselves worthy of a position and leadership roles. This kind of pressure leaves Black people feeling that they cannot make mistakes, and their mistakes will be viewed as a sign of incompetence. This was the sentiment expressed by the school leaders. An elementary school principal noted:

\begin{abstract}
There is not a lot of room to make mistakes ... because they will consider you incompetent and things like that...I went through a season when I was oblivious to it and then I went through a phase where there was a lot of tension and it got me angry. Now I am in a season where I am working through it...through these tensions you are going to have to use wisdom...cannot show that you're frustrated put your best face on every day, find outlets where you can download outside of the building. . .
\end{abstract}

These stresses have negative impact on the health of Black people. It causes stress and other complications such as anxiety, depression, and feelings of worthlessness due to persistent fear (Holder, Jackson, \& Ponterotto, 2014).

Anti-Black racism was also manifested in the lack of mentorship to assume leadership positions afforded to non-Black staff, and as one participant noted she had to "carve out her own path." Support and opportunities that were given to their White counterparts were not given to them. For example, chairing committees and participating in system wide initiatives that showcased their leadership capacity. A vice principal said that when she became a vice principal, it was a steep learning curve for her because of lack of mentoring and support.

Being a racialized educational leader is more challenging. I've had a lot of leadership experiences but I've also had to carve them out myself. . . .I noticed that a lot of the opportunities are given to other members of staff, who were not racialized. When I would ask I to be included I was told that I did not need those experiences as I know a lot already these experiences.... if you want to move forward as a leader in your school or within the Board you have to create opportunities for yourself. . I had to begin to create opportunities for myself.

Anti-Blackness is also experienced when as a Black person you are not thought of as having leadership qualities compared to White people where society assumes that they are capable of leadership and Black people incapable. A secondary resource teacher who was seeking a promotion to become a vice principal noted that when she was applying to become a vice principal she "found a lot of challenges in her way" including lack of mentoring and support. Mentoring is important to support both aspiring leaders and those who are in formal roles, supports the development leadership skills, and provides sustenance on the leadership journey (Lopez, 2013, 2016).

Many of the Black school leaders felt that they while it was not said they were responsible for the success of Black students they felt responsible. While community 
is an important aspect of the experiences of Black people, some school leaders felt that the needs of Black students were left entirely up to them, as some White teachers and principals did not want spend to the time getting to know Black kids so that they could support their learning in meaningful ways. A secondary school principal noted that some guidance counselors in her school directed Black students away from areas such as Law and Medicine and directed them to other careers. A secondary school principal shared an experience where a Black student was directed "to become a paralegal instead of going to university to become a lawyer". She noted that she was "constantly having difficult conversations with guidance counselors". She felt these actions "were racist, demeaned students and lowered their expectations of themselves". James and Turner (2017) found that in the Ontario school system Black students are more likely to be streamed in applied classes that lead to college, instead of academic classes that lead directly to university. James and Turner also found that smaller proportion of Black students are enrolled in the academic program of study, while a larger proportion of Black than White and other racialized students were enrolled in the applied and essentials programs.

The school leaders also experienced dissonance and anti-Black racism with the discipline and control phenomenon that they were asked to participate in as Black school leaders, and inflicted primarily upon students of color. This was an area of pain and great discomfort as they felt their agency in resisting was restricted by policies and practices in place in their schools. At times, they felt voiceless and complicit when they were unable to intervene and change the outcome for students, while at the same time recognizing that the discipline that Black youths were experiencing, inflicted by both Black and White school leaders were grounded in the historical construction of the Black body, what it represents in educational spaces sowed where the perpetuation of oppression had not been disrupted. A secondary principal shared the pain she felt when she had to suspend yet another Black boy for breaking the school rules and "impacting the safety of others and their learning." She noted:

It is bothers me when I see the Black boys caught up in the cycle and then forced out by disciplinary practices that do not see them as worthy and valuable. They become disengaged, do not go to class, because their teachers make little effort to connect with them. . .their main goal is to control them and it becomes a cycle of disengagement and punishment. . .I watch the parents come in ...I see the pain on their faces...I offer words of advice and watch the same scene play over and over again like a movie... I feel their pain and see their worry because I am a mother too... .

Gregory, Skiba and Noguera (2010) suggests that we should be alarmed at the number of Black students being disciplined and suggest that this has become the new equity issue as educators wrestle with the disproportionate number of incidents of school discipline involving Black students. Black students outnumber all other groups in every aspect of the disciplinary system (Gregory, Skiba \& Noguera, 2010). Black childrens bodies can represent the ultimate threat to authority; the disciplining of Black children can be understood as the definitive reinforcement of security and order (Dumas \& Ross, 2016). Black students more than any other group 
are subjected to harsh disciplinary actions, zero tolerance policies, and the criminalization of student behavior (Hirschfield, 2008). According to Dumas and Ross (2016), the disciplining of Black children must be understood in the context of larger systems of repression as this is necessary in implementing strategies in public schools that effectively educate Black children.

Drawing on my own lived experiences as a school leader and administrator in the GTA I have experienced anti-Black racism when colleagues express shock dismay when I advocate for myself and engage in learning and professional development activities directed to my own educational growth. In one instance after I signed up to attend a workshop, another administrator suggested that "she did not see why I was attending" and suggested that I "remain in the building." Similar suggestions were not made to the White administrator. In another incident, I was at a professional development workshop when everyone was asked where they lived. When I shared the name of the small town where I lived, a White principal said that she was not "aware that there were apartment buildings in that town." That incident for me is an example of how Black bodies are positioned in certain spaces.

A secondary school principal's narrative in many summarizes and highlights how racial micro aggressions are inflicted on the Black people facilitated through and anti-Black racism. She noted:

\begin{abstract}
When you are a racialized person aspiring to move into administration, you have a lot of challenges in the way ... the reason I say that is there are so many opportunities that White teachers get. . . being teacher in charge, engage in Board initiatives, opportunities to make timetables and things like that. I've never had any of these opportunities so most of the leadership stuff that I have done I just carved out on my own. . . when I got promoted to vice principal the job was a huge learning curve for me, while other people, my White colleagues had been provided leadership opportunities.
\end{abstract}

Hernandez and Murakami (2016) suggest the historically marginalizing emblems of identity such as race, gender, and language are often undocumented and invisible in the school leadership research and more work needs to be done in this area. The narratives of the school leaders remind us that the challenges that racialized school leaders face are real, complex, and challenging. Leseho and Block (2005) suggest that it is important to tell our stories as we live them, as storytelling is a path to healing for oppressed and marginalized communities.

\title{
Discussion
}

In Ontario, the teaching staff and those in leadership remain predominantly White, notwithstanding the rapidly changing demographics (Segeren, 2016; Turner, 2015). Within the discourse of equity, diversity, and social justice that permeates education, these examples serve as reminders that anti-Black racism remains a dominant force in education in Canada. As schools work to diversify teaching staffs and administrators in school districts, anti-Black racism must be named and examples of how it is manifested in school leadership brought to the forefront. White supremacy, and how 
it is manifested in schools must also be named. Educators, and in particular those who benefit from the system through existing norms and practices must engage in a process of unlearning and learning acknowledging the impact of neoliberalism in education in their everyday work.

These stories are useful when creating policies to recruit, support, and retain Black school administrators. By acknowledging the existence, anti-Black racism Black people will feel more comfortable entering spaces. Anti-Black racism is often experienced through daily micro-aggressions and mentoring is a way to support Black school leaders to stay the journey. I posit collaborative mentorship (Lopez, $2005,2013,2016)$ as a form of support. In this form of mentorship, the notion of protégé and expert is replaced with the notion of co-laboring. This form of mentorship does not necessarily have to be with a Black person, but the mentor must have engaged in reflective practice coming to terms with how white supremacy and antiBlack racism are manifested. In some instances, some Black people might have to begin the journey of decolonizing their mind and be fully grounded in their identity. In the collaborative mentorship relationship, space must be created for critical dialogue. This relationship is ongoing and is a space for deep learning for both mentor and mentee.

For Black people our stories can be a form of resistance and healing. Nora (2015) suggests that educational institutions are not only spaces where Black people are unconsciously subjected to the ideology of the dominant group but spaces where they come to understand the consciousness of their position and power. Our survival in these spaces requires understanding our location and positionality in forging a critical (Freire, 1970), anti-colonial (Simmons \& Dei, 2012), decolonizing (Wa Thiong'o, 1986) educational journey. Colonization involves the mental domination of the colonized and we must break ourselves free from this domination (Wa Thiong'o, 1986). We must pay attention to dominant discourses of influence (Smith, 2012b). There must be a renewed spiritual grounding within our African identity and consciousness in opposition to Eurocentric knowledge (Mazama 1998). Decolonizing educational praxis disturbs the structural as well as the functional coherence of official knowledges and Eurocentric metanarratives (Abdi, 2012).

Sometimes it is difficult to cope with the pressures to conform and Black people reproduce colonizing agendas through formal and informal expectations in the workplace (McDowell \& Hernandez 2010). Oppressive social systems can negatively affect the identities of subjugated people who might experience cultural estrangement and disconnection from their cultural histories (Sonn \& Green, 2006). Decolonizing ideologies and practices offer opportunities to decenter dominant discourses and loosen the grip of neocolonial paradigms (Denzin \& Lincoln, 2008). While I recognize that Blackness is not a homogenized experience for all Black people, we must speak about our own experiences and perspectives. Decolonizing education advances collaboration, affirms our heritage, moves beyond tolerance of difference, and challenges racist ideology as we rethink and re-imagine ourselves in relationship with one another (Bouvier, 2013). Racism is a permanent fixture enmeshed in the fabric of society and the social order of things including 
education for people of color, as such we must use our collective voices as resistance, offering new transformative praxis.

\section{Conclusion}

The OECD (2008) suggests that school leadership has emerged as one of the most important policy issues around the world. We also know from data that Black youth in the USA, Canada, and other advanced economies are not achieving to their full potential. The challenges of public education in meeting the needs of students of color do not rest on the children, but in the systems and practices that are not meeting their needs. School leaders have a role to play in making schools more responsive to the needs of students. Second to teaching, leadership has the greatest impact on the learning outcomes of students (Leithwood, Seashore Louis, Anderson \& Wahlstrom, 2004). As schools become more diverse, social justice, equity, culturally responsive education, and diversity have taken on grater significance in educational discourse, practice, and policy. While great strides have been made, James and Turner (2017) and other scholars remind us that some Black, Indigenous and other students of color are not experiencing the outcomes compared to other groups.

In this chapter, drawing on the stories of Black school leaders in the GTA, undergirded by CRT and anti-Black racism theorizing I argue that it is important for anti-Black racism to be named and identified within school leadership discourse so that school leaders can develop insights on ways that students of color continue to be oppressed and take action. I agree with Dumas and Ross (2016) who argue that the education of Black children must be understood in the context of larger systems of repression as this is necessary in implementing strategies in public schools that effectively educate them. School leaders are important in achieving this important goal. By school leaders sharing their experiences and stories as they navigate their leadership journey, we gain deeper insights into ways that anti-Black racism is manifested in schools. I seek transformative change in the quest to improve the lives of Black people and other all those who are oppressed in educational settings. We must challenging systems and practices that continue to exclude (Newton, 2017) and suggest strategies and policies that address the challenges we face particularly in Ontario as we seek to diversify all aspects of education to be more reflective of the students that occupy schools.

\section{References}

Abdi, A. (Ed.). (2012). Decolonizing philosophies of education. Rotterdam, Netherlands: Sense Publishers.

Aylward, C. (1999). Canadian critical race theory: Racism and the law. Halifax/Nova Scotia: Fernwood Publishing.

Bauer-Wolf, J. (2017). A September of racist incidents. Inside Higher Ed. Retrieved from https:// www.insidehighered.com/news/2017/09/22/racist-incidents-colleges-abound-academic-yearbegins. 
Benjamin, A. (2011). Afterword: Doing anti-oppressive social work: The importance of resistance, history and strategy. In D. Baines (Ed.), Doing anti-oppressive practice: Social justice social work (pp. 290-297). Halifax, Canada: Fernwood Press.

Bouvier, V. (2013). Truthing: An ontology of living an ethic of shakihil (love) and ikkimmapiiyipitsiin (sanctified kindness). Canadian Social Studies, 50(2), 39-44. Retrieved from https://files.eric.ed.gov/fulltext/EJ1200074.pdf.

Bruner, J. (2002). Narratives of human plight: A conversation with Jerome Bruner. In R. Charon \& M. Montello (Eds.), Stories matter - The role of narrative in medical ethics (pp. 3-9). New York: Routledge.

City of Toronto. (2017). The Toronto action plan to confront anti-black racism. Retrieved from https://www.toronto.ca/legdocs/mmis/2017/ex/bgrd/backgroundfile-109126.pdf.

Clandinin, D. J., \& Connelly, F. M. (2000). Narrative inquiry: Experience and story in qualitative research. San Francisco: Jossey-Bass.

Creswell, J. W. (2013). Qualitative inquiry and research design: Choosing among five approaches (3rd ed.). Thousand Oaks, CA: Sage.

Dei, G. J. S. (2003). Schooling and the dilemma of youth disengagement. McGill Journal of Education, 38(3), 241-256.

Delgado, R. (2009). Liberal McCarthyism and the origins of critical race theory. Iowa Law Review, 94, 1505-1545.

Delgado, R., \& Stefancic, J. (2000). Introduction. In R. Delgago \& J. Stefanic (Eds.), Critical race theory: The cutting edge (2nd ed., pp. xv-xix). Philadelphia: Temple University Press.

Delgado, R., \& Stefancic, J. (2007). Critical race theory and criminal justice. Humanity and Society, 31(May/August), 133-145.

Denzin, N. K., \& Lincoln, Y. S. (2008). Strategies of qualitative inquiry. The Sage handbook of qualitative research (3rd ed.) Thousand Oaks, CA: Sage.

Doret, P., \& Gordon, P. (2018). Anti-black racism, bio-power, and governmentality: Deconstructing the suffering of black families involved with child welfare. Journal of Law and Social Policy, 28,81 . Retrieved from https://digitalcommons.osgoode.yorku.ca/jlsp/vol28/iss1/5

Dumas, M. J., \& Ross, K. M. (2016). "Be real black for me": Imagining BlackCrit in education. Urban Education, 51(4), 415-442.

Fallace, T. (2017). American educators' confrontation with fascism. Educational Researcher, 47(1), $46-52$.

Feagin, J. (2013). Systemic racism: A theory of oppression. New York, NY: Routledge.

Feagin, J. R., Hernan, V., \& Imani, N. (1996). The agony of education: Black students at white colleges and universities. New York, NY: Routledge.

Freire, P. (1970). Pedagogy of the oppressed. New York, NY: The Continuum International Publishing Group Inc.

Gillborn, D. (2015). Intersectionality, critical race theory, and the primacy of racism: Race, class, gender, and disability in education. Qualitative Inquiry, 21(93), 277-287.

Gillborn, D. (2018). Heads I win, tails you lose: Anti-black racism as fluid, relentless, individual and systemic. Peabody Journal of Education, 93(1), 66-77.

Giroux, H. A. (2017). White nationalism, armed culture and state violence in the age of Donald Trump. Philosophy and Social Criticism, 43(9), 887-910.

Gregory, A., Skiba, R., \& Noguera, P. (2010). The achievement gap and the discipline gap: Two sides of the same coin? Educational Researcher, 39, 59-68.

Hernandez, F., \& Murakami, E. (2016). Counterstories about leadership: A Latina school principal's experience from a less documented view in an urban school context. Education Sciences, 6(6), 1-16. Retrieved from www.mdpi.com/2227-7102/6/1/6/pdf

Hirschfield, P. J. (2008). Preparing for prison? The criminalization of school discipline in the USA. Theoretical Criminology, 12, 79-101.

Holder, A. M. B., Jackson, M. A., \& Ponterotto, J. G. (2014). Racial microaggression experiences and coping strategies of black women in corporate leadership. Qualitative Psychology, 2(2), $164-180$. 
James, C. E., \& Turner, T. (2017). Towards race equity in education: The schooling of black students in the Greater Toronto Area. Toronto, ON: York University.

Kafele, B. K. (2012). Empowering young black males. Educational Leadership, 70(2), 67-70.

Kohli, R., PizaRRo, M., \& NeváRez, A. (2017). The "new racism" of K-12 schools: Centering critical research on racism. Review of Research in Education, 41(3), 182-202.

Kumsa, M. K., Mfaofo-M'Carthy, M., Oba, F., \& Gaasim, S. (2014). The contours of anti-black racism: Engaging anti-oppression from embodied spaces. The Journal of Critical Anti-Oppressive Social Inquiry, 1, 21-38.

Ladson-Billings, G., \& Tate, W. F. (1995). Toward a critical race theory of education. Teachers College Record, 97, 47-68.

Ladson-Billings, G. (1998). Just what is critical race theory and what's it doing in a nice field like education? International Journal of Qualitative Studies in Education, 11(1), 7-24.

Leithwood, K., Seashore Louis, K., Anderson, S., \& Wahlstrom, K. (2004). How leadership influences student learning: A review of research for the learning from leadership project. New York, NY: The Wallace Foundation.

Leseho, J., \& Block, L. (2005). "Listen and I tell you something": Storytelling and social action in the healing of the oppressed. British Journal of Guidance and Counselling, 33(2), 175-197.

Lewis, A. E., Chesler, M., \& Forman, T. A. (2001). The impact of "colorblind" ideologies on students of color: Intergroup relations at a predominantly white university. Journal of Negro Education, 69, 74-91.

Lopez, A. E. (2005). The role and impact of experiential collaborative mentorship as a form of teacher support in anti-racist education. In: Paper presented at the Canadian Society for Studies in Education (CSSE). London, England: University of Western Ontario.

Lopez, A. E. (2013). Collaborative mentorship: A mentoring approach to support and sustain teachers for equity and diversity. Mentoring and Tutoring: Partnership in Learning, 21(3), 292-211.

Lopez, A. E. (2016). Culturally responsive and socially just leadership: From theory to action. New York, NY: Palgrave Macmillan.

Matsuda, M. J., Lawrence, C. R., Delgado, R., \& Crenshaw, K. W. (Eds.). (1993). Words that wound: Critical race theory, assaultive speech, and the first amendment. Boulder, CO: Westview Press.

Mazama, A. (1998). The Eurocentric discourse on writing: An exercise in self-glorification. Journal of Black Studies, 29(1), 3-16.

McDowell, T., \& Hernandez, P. (2010). Decolonizing academia: Intersectionality, participation, and accountability in family therapy and counselling. Journal of Feminist Family Therapy, 22(2), 93-111.

McLaren, P. L. (1995). White terror and oppositional agency: Towards a critical multiculturalism. In C. E. Sleeter \& P. L. McLaren (Eds.), Multicultural education, critical pedagogy, and the politics of difference (Vol. 4, pp. 33-70). New York, NY: State University of New York Press.

Melamed, J. (2011). Represent and destroy. Minneapolis, MN: University of Minnesota.

Mullings, D., Morgan, A., \& Quelleng, H. K. (2016). Canada the great white north where anti-black racism thrives: Kicking down the doors and exposing the realities. Phylon (1960-), 53(1), $20-41$.

Newton, J. (2017). Anti-black racism, resistance, and the health and Well-being of black bodies in public education. In J. Newton \& A. Soltani (Eds.), New framings on anti-racism and resistance. Rotterdam, Netherlands: Sense Publishers.

Noguera, P. (2003). The trouble with black boys: The role and influence of environmental and cultural factors on the academic performance of African-American males. Urban Education, $38(4), 431-459$.

Office of the United Nations High Commissioner for Human Rights (OHCHR). (2016). Working Group of Experts on People of African Descent. Statement to the media by the United Nations. Working Group of Experts on People of African Descent, on the conclusion of its official visit to 
Canada. Retrieved from http://www.ohchr.org/EN/NewsEvents/Pages/DisplayNews.aspx? NewsID $=20732 \&$ LangID $=$ E.

Organization for Economic Co-operation and Development. (2008). Improving school leadership. Retrieved from https://www.oecd.org/education/school/improvingschoolleadership-home.htm

Ruck, M., \& Wortley, S. (2002). Racial and ethnic minority high school students' perceptions of school disciplinary practices: A look at some Canadian findings. Journal of Youth and Adolescence, 31(3), 185-195.

Segeren, A. L. (2016). How schools enact equity policies: A case study of social justice leadership (Electronic thesis and dissertation repository). 4137. https://ir.lib.uwo.ca/etd/4137

Sexton, J. (2007). Racial profiling and the societies of control. In J. James (Ed.), Warfare in the American homeland: Policing and prison in a penal democracy (pp. 197-218). Duke University Press Books.

Sexton, J. (2010). People-of-color-blindness notes on the afterlife of slavery. Social Text, 28(2/103), $31-56$.

Sexton, J. (2015). Unbearable blackness. Cultural Critique, 90, 159-178.

Simmons, M., \& Dei, G. S. (2012). Reframing anti-colonial theory for the diasporic context. Postcolonial Directions in Education, 1(1), 67-99.

Smith, L. T. (2012a). Decolonizing methodologies: Research and indigenous peoples. New York, NY: Zed Books.

Smith, A. (2012b). Indigeneity, settler colonialism, white supremacy. In D. Hosang, O. LaBennett, \& L. Pulido (Eds.), Racial formation in the twenty-first century. Berkeley, CA: University of California Press.

Sojoyner, D. (2013). Black radicals make for bad citizens: Undoing the myth of the school to prison pipeline. Berkeley Review of Education, 4(2), 241-263.

Sonn, C. C., \& Green, M. J. (2006). Disrupting the dynamics of oppression in intercultural research and practice. Journal of Community and Applied Social Psychology, 16, 337-346.

Taylor, J. (2016). The foundations of critical race theory in education. In E. Taylor, D. Gillborn, \& G. Ladson-Billings (Eds.), Foundations of critical race theory in education (2nd ed., pp. 1-11). New York, NY: Routledge.

Tinsley-Jones, H. (2003). Racism: Calling a spade a spade. Psychotherapy: Theory, Research, Practice, Training, 40(3), 179-186.

Trahar, S. (2013). Contextualising narrative inquiry: Developing methodological approaches for local contexts. Hoboken, NY: Taylor and Francis.

Turner, T. (2015). Voices of Ontario black educators: An experiential report, Ontario Alliance of Black School Educators. (ONABSE). Turner Consulting Group. Retrieved 20 September 2016, from http://onabse.org/ONABSE_VOICES_OF_BLACK_EDUCATORS_Final_Repot.pdf

Vogt, W. P. (1999). Dictionary of statistics and methodology: A nontechnical guide for the social sciences. London: Sage.

Wang, C. C., \& Geale, S. K. (2015). The power of story: Narrative inquiry as a methodology in nursing. International Journal of Nursing Sciences, 2(3), 195-198.

Wa Thiong'o, N. (1986). Decolonising the mind - The politics of language in African literature. Nairobi, Kenya: Heinemann Kenya.

Wallace, J. M., Jr., Goodkind, S., Wallace, C. M., \& Bachman, J. G. (2008). Racial, ethnic, and gender differences in school discipline among US high school students: 1991-2005. The Negro Educational Review, 59(1-2), 47.

Warmington, P. (2014). Black British intellectuals and education: Multiculturalism's hidden history. London, England: Routledge.

Wun, C. (2016). Unaccounted foundations: Black girls, anti-black racism, and punishment in schools. Critical Sociology, 42(4-5), 737-750. 